J. AMER. Soc. HorT. SCI. 115(3):390-394. 1990.

\title{
Fruit Abscission and Fruit Quality of Apples Following Use of Dicamba to Control Preharvest Drop
}

\author{
Richard P. Marini ${ }^{1}$, Ross E. Byers ${ }^{2}$, Donald L. Sowers ${ }^{3}$, and Rodney W. Young ${ }^{4}$ \\ Department of Horticulture, Virginia Polytechnic Institute and State University, Blacksburg, \\ VA 24061
}

Additional index words. Malus domestica, NAA, PGR, herbicide, stop drop

\begin{abstract}
Five apple (Malus domestica Borkh.) cultivars were treated with dicamba at concentrations of 0 to 200 mg-liter $^{-1}$ during 3 years. Although the response varied with cultivar, dose, and year, dicamba always delayed fruit abscission. At similar concentrations, dicamba usually reduced fruit drop more than NAA, but less than fenoprop. Dicamba at $10 \mathrm{mg} \cdot \mathrm{liter}^{-1}$ effectively delayed drop of 'Delicious', whereas 20 to $30 \mathrm{mg} \cdot \mathrm{liter}^{-1}$ was required for 'Red Yorking', 'Rome', 'Winesap', and 'Stayman'. Dicamba did not influence flesh firmness, soluble solids content, water core, or starch content at harvest or after storage. Chemical names used: naphthaleneacetic acid (NAA); 2-(2,4,5trichlorophenoxy)propionic acid (fenoprop); 3,6dichloro-2-methoxybenzoic acid (dicamba).
\end{abstract}

Apples often abscise before developing adequate color and maturity for harvest. Some years, more than one half of the crop may be lost to preharvest drop. Until recently, naphthaleneacetic acid (NAA), 2(2,4,5-trichlorophenoxy)propionic acid (fenoprop), and butanedioic acid mono(2,2-dimethylhydrazide) (daminozide) were used alone (Gardner et al., 1940; Batjer and Williams, 1966; Mattus et al., 1956) or in combination (Pollard, 1974; Edgerton and Blanpied, 1970) to delay apple fruit abscission. Since the registration for fenoprop was recently suspended and since daminozide is no longer sold, NAA remains the only material registered to delay apple abscission. Lateseason processing cultivars often exhibit excessive fruit drop because NAA is effective for only 7 to 14 days (Mattus et al., 1956; Southwick et al., 1953) and adequate labor is often not available to rapidly harvest large orchards, especially during rainy harvest seasons.

The herbicide 3,6dichloro-2-methoxybenzoic acid (dicamba) exhibited stop-drop activity on apple in preliminary tests (Marini and Byers, 1988), but appropriate concentrations were not identified. This study was performed to determine the optimum concentration of dicamba for delaying fruit abscission and to study its influence on fruit maturity and storability.

\section{Materials and Methods}

1986-Winchester. Ten-year-old 'Fullred Delicious'/seedling trees at Winchester, Va., were treated at 140 days after full bloom (DAFB) on 9 Sept. There were five single-tree replicates in a randomized complete-block design (RCBD). Treatments were an unsprayed control, fenoprop at $10 \mathrm{mg}$ a.i./liter, and dicamba (formulated as $40 \%$ E.C., $48.2 \%$ dimethylamine salt of dicamba; Sandoz Crop Protection, Des Plaines, Ill.) at 200 $\mathrm{mg}$ acid equivalent/liter. Treatments were applied to whole trees with an airblast sprayer at 2800 liters.ha ${ }^{-1}$. Buffer trees were left between treated trees within and between treated rows. Three limbs per tree, with 10 to 20 fruit per limb, were marked and

\footnotetext{
Received for publication 19 June 1989. The cost of publishing this paper was defrayed in part by the payment of page charges. Under postal regulations, this paper therefore must be hereby marked advertisement solely to indicate this fact.

${ }^{1}$ Associatcd Professor of Horticulture.

${ }^{2}$ Professor of Horticulture, Winchester Agr. Expt. Sta., Winchester, VA 22601. ${ }^{3}$ Research Technician.

${ }^{4}$ Professor of Biochemistry and Nutrition.
}

fruit were counted before treatment and periodically thereafter for 4 weeks. On each date, data were expressed as the cumulative percentage of the fruit that abscised from each limb. At 14 and 28 days after treatment, 20 fruit were sampled from around each tree. A sample of 10 fruit per tree was evaluated for flesh firmness and soluble solids concentration (SSC) on the following day. The remaining 10 fruits were stored at $1 \mathrm{C}$ for evaluation on 12 Dec.

1987-Winchester. 'Fullred Delicious' trees were treated on 3 Sept. (126 DAFB). The trees and methods were similar to those described for 1986, except fruit maturity was not evaluated. The treatments were dicamba at $0,6.25,12.5,25,50$, and $100 \mathrm{mg}$ acid equivalent/liter, and NAA at $10 \mathrm{mg}$ a.i./liter. 'Red Yorking'/MM.111 trees were treated on 25 Sept. (155 DAFB) with dicamba at $0,1,5,10,20$, and $40 \mathrm{mg}$ acid equivalent/liter.

1987-Blacksburg. Twenty-year-old 'Rome' and 'Stayman' trees on MM.111 rootstock growing at Blacksburg, Va., were treated on 30 Sept. (158 DAFB). Trees were sprayed with a handgun to runoff at 4040 liters.ha ${ }^{-1}$. There were three 'Rome' trees (single-tree replicates) per treatment in a RCBD, and the treatments included dicamba at $0,5,10$, and $20 \mathrm{mg}$ acid equivalent/liter. There were four 'Stayman' trees per treatment in single-tree plots in a RCBD, and the treatments included dicamba at $0,5,10,20$, and $40 \mathrm{mg}$ acid equivalent/liter. Three limbs per tree with 15 to 20 fruit per limb were marked and fruit were counted periodically for 4 weeks. On each date, data were expressed as the cumulative percentage of the fruit that had abscised from each limb.

1988-Winchester. 'Fullred Delicious' trees were treated on 1 Sept. (126 DAFB). There were six single-tree replicates in a RCBD and the methods were similar to those reported for 1986. Treatments included nonsprayed control trees, NAA at 10 $\mathrm{mg} \cdot$ liter $^{-1}$, and dicamba at $5,10,15$, and $20 \mathrm{mg}$ acid equivalent/liter. Fruit abscission data were recorded as described for the 1986 and 1987 experiments.

1988-Blacksburg. Six-year-old 'Redchief Delicious'/MM.111 trees were treated on 14 Sept. (135 DAFB). Treatments were sprayed with a handgun to runoff at 1620 liters $\cdot \mathrm{ha}^{-1}$. Treatments included an unsprayed control, NAA at $10 \mathrm{mg}$ a.i./liter, fenoprop at $10 \mathrm{mg}$ a.i./liter, and dicamba at $5,10,15$, or 20 $\mathrm{mg}$ acid equivalent/liter. There were eight single-tree replicates per treatment in a RCBD. The fruit under each tree were counted and removed at 2- to 4-day intervals for 37 days. On 20 Oct., 
all fruit remaining on the trees were harvested and counted. The cumulative percentage fruit drop on each date was based on the number of fruit that was originally on the tree. One, 2, and 3 weeks after treatment, 10 fruit were sampled from around each tree. The maturity of a sample of five fruits per tree was evaluated on the following day. The remaining five fruits were stored at 1C for evaluation on 9 Jan. 1989. Flesh firmness was measured on two sides of each fruit with an Effegi penetrometer (Model FT 327; McCormick Fruit Tech, Yakima, Wash.) fitted with an 11.1-mm tip. Soluble solids concentration was estimated with an Atago hand-held refractometer (Model N1, McCormick Fruit Tech). Each fruit was cut in half transversely and severity of water core was rated on a scale of 1 to 7 (1 = none and $7=$ severe). Flesh starch was evaluated by dipping one half of each fruit in iodine solution for $1 \mathrm{~min}$; the degree of staining was rated on a scale of 1 to 9 , where $1=$ staining of the entire cut surface and $9=$ the absence of starch (Poapst et al., 1959).

Twenty-one-year-old 'Rome', 'Winesap', and 'Red Yorking'/MM.111 trees were sprayed with a handgun to runoff on 3 Oct. (164 DAFB) at the rate of 4040 liters $\cdot \mathrm{ha}^{-1}$. There were five single-tree replicates per treatment in a RCBD. Treatments included a nonsprayed control, NAA at $20 \mathrm{mg}$ a.i./liter, and dicamba at 10, 20, and $30 \mathrm{mg}$ acid equivalent/liter. Three limbs per tree carrying 10 to 15 fruit were marked, and fruit were counted before treatment and every 2 to 4 days thereafter for 4 weeks. On each date, data were expressed as the cumulative percentage of the fruit that abscised from each limb. One week after treatment, 10 fruits were sampled from around the canopy of each 'Winesap' tree. The maturity of a sample of five fruits per tree was evaluated on the following day. The remaining five fruits were stored at 1C for evaluation on 9 Jan. 1989.

Statistical analyses. Percentage data were transformed to the arcsin of the square root of the proportion. Data were analyzed using the analysis of variance (ANOVA) and GLM procedures of SAS (SAS Institute, Inc., 1982). Since ANOVA usually indicated a significant treatment by date interaction for drop data, ANOVA was performed for each measurement date and selected means were compared with single degree-of-freedom contrasts. Where appropriate, linear and nonlinear regression was performed to test the effect of dicamba concentration on various dependent variables.

\section{Results}

1986. Fenoprop reduced drop relative to the control for 34 days, while dicamba was only effective after 21 days following application (Table 1). Drop did not differ between dicamba and fenoprop. Most of the fruit drop for dicamba- and fenoproptreated trees occurred within 1 week of treatment, with little

Table. 1, Influence of dicamba and fenoprop on abscission of 'Fullred Delicious' fruit at Winchester. Va., in 1986.

\begin{tabular}{lccccccc}
\hline \hline & & \multicolumn{5}{c}{$\begin{array}{c}\text { Cumulative drop at the } \\
\text { following days after } \\
\text { treatment (\%) }\end{array}$} \\
\cline { 3 - 7 } Chemical & $\begin{array}{c}\text { Conen } \\
\left(\text { mg-liter }^{-1}\right)\end{array}$ & 7 & 14 & 21 & 18 & 34 \\
\hline None & -5 & $25 \mathrm{a}$ & $39 \mathrm{a}$ & $59 \mathrm{a}$ & $73 \mathrm{a}$ & $77 \mathrm{a}$ \\
Dicamba & 200 & $19 \mathrm{ab}$ & $21 \mathrm{ab}$ & $21 \mathrm{~b}$ & $23 \mathrm{~b}$ & $23 \mathrm{~b}$ \\
Fenoprop & 10 & $8 \mathrm{~b}$ & $9 \mathrm{~b}$ & $9 \mathrm{~b}$ & $12 \mathrm{~b}$ & $13 \mathrm{~b}$ \\
\hline
\end{tabular}

${ }^{z}$ Percentage values are means of 15 observations.

${ }^{y}$ Mean separation within columns by Duncan's multiple range test $(P$ $=0.05)$. additional drop occurring during the next 4 weeks. These treatments did not significantly affect the firmness (range $78-79 \mathrm{~N}$, 24 Sept.; 66-69 N, 7 Oct.) or SSC (range 12.2\%-12.9\%, 24 Sept.; $13.7 \%-14.2 \%, 7$ Oct.) of fruit harvested the 2 or 4 weeks after treatment. Within a month of treatment, leaves on dicamba-treated trees appeared chlorotic and leaf abscission was accelerated. About $25 \%$ of the fruit on dicamba-treated trees never abscised. The fruit pedicels decayed during the winter and spring, and the spurs to which they were attached usually died. The following spring, the trees had very little bloom and exhibited herbicide phytotoxicity symptoms, such as small, malformed leaves; delayed budbreak; and die-back of previous season's shoots. Symptoms were less obvious 1 month after bloom and growth appeared normal by mid-summer. Tree growth, bloom, and fruit set in 1988 appeared similar to control trees. Phytotoxic symptoms were not observed in any of the other experiments where dicamba concentrations did not exceed 100 mg.liter ${ }^{-1}$.

1987. Fruit drop of 'Fullred Delicious' was negatively related, in a quadratic manner, to dicamba concentration throughout the experimental period (Table 2). NAA at $10 \mathrm{mg} \cdot \mathrm{liter}^{-1}$

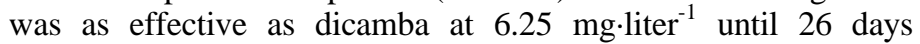
after treatment (DAT), but was less effective thereafter. Drop

Table 2. Influence of NAA and dicamba on abscission of 'Fullred Delicious' fruit at Winchester, Va, in 1987.

\begin{tabular}{|c|c|c|c|c|c|c|c|}
\hline \multirow[b]{2}{*}{ Chemical } & \multirow{2}{*}{$\begin{array}{c}\text { Concn } \\
\left(\mathrm{mg} \cdot \text { liter }^{-1}\right)\end{array}$} & \multicolumn{6}{|c|}{$\begin{array}{l}\text { Cumulative drop at the } \\
\text { following days } \\
\text { after treatment }(\%)\end{array}$} \\
\hline & & 12 & 19 & 26 & 33 & 42 & 47 \\
\hline None & $\cdots$ & 14 & 49 & 70 & 80 & 87 & 89 \\
\hline \multirow[t]{5}{*}{ Dicamba } & 6.25 & 0 & 8 & 14 & 26 & 36 & 40 \\
\hline & 12.5 & 0 & 2 & 4 & 12 & 21 & 24 \\
\hline & 25 & 1 & 2 & 2 & 5 & 10 & 11 \\
\hline & 50 & 1 & 2 & 3 & 4 & 5 & 6 \\
\hline & 100 & 1 & 3 & 4 & 6 & 8 & 8 \\
\hline NAA & 10 & 2 & 8 & 19 & 46 & 53 & 56 \\
\hline Significance ${ }^{z}$ & & NS & $\mathrm{L}, \mathrm{Q}$ & $\mathrm{L}, \mathrm{Q}$ & $\mathrm{L}, \mathrm{Q}$ & $\mathrm{L}, \mathrm{Q}$ & $\mathrm{L}, \mathrm{Q}$ \\
\hline Model $R^{2}$ & & -- & 0.33 & 0.49 & 0.63 & 0.72 & 0.74 \\
\hline \multirow{3}{*}{$\begin{array}{l}\text { NAA vs. control } \\
\text { NAA vs. dicamba at } \\
6.25 \mathrm{mg} \cdot \text { liter }^{-1} \\
\end{array}$} & & & & & & & \\
\hline & $\cdots$ & 0.01 & 0.01 & 0.01 & 0.01 & 0.01 & 0.01 \\
\hline & & 0.66 & 0.95 & 0.50 & 0.01 & 0.02 & 0.04 \\
\hline
\end{tabular}

${ }^{\mathrm{z}}$ Statistical significance levels were assessed at $P \leq 0.05(\mathrm{n}=30)$; NS represents nonsignificance, and L and Q represent significant linear and quadratic terms, respectively.

Table 3. Abscission of 'Red Yorking' apples following application of dicamba at Winchester, Va., in 1987.

\begin{tabular}{ccccccc}
\hline \hline \multirow{2}{*}{$\begin{array}{c}\text { Concn } \\
\left.\text { (mg-liter }{ }^{-1}\right)\end{array}$} & \multicolumn{5}{c}{$\begin{array}{c}\text { Cumulative fruit drop at the following days after } \\
\text { treatment }(\%)\end{array}$} \\
\cline { 2 - 8 } & 7 & 28 & 35 & 41 & 49 & 56 \\
\hline 0 & 5 & 14 & 19 & 30 & 64 & 87 \\
1 & 7 & 15 & 20 & 35 & 63 & 84 \\
5 & 2 & 7 & 13 & 23 & 52 & 69 \\
10 & 2 & 6 & 8 & 16 & 46 & 70 \\
20 & 2 & 6 & 9 & 17 & 34 & 57 \\
40 & 1 & 5 & 9 & 16 & 34 & 42 \\
Significance & NS & L,Q & L,Q & L,Q & L,Q & L,Q \\
Model $R^{2}$ & --- & 0.34 & 0.38 & 0.40 & 0.55 & 0.62 \\
\hline
\end{tabular}

${ }^{\mathrm{z}}$ Statistical significance levels were assessed at $P \leq 0.05(\mathrm{n}=24)$; NS represents nonsignificance, and L and $Q$ represent significant linear and quadratic terms, respectively. 
Table 4. Influence of dicamba on abscission of 'Rome' and 'Stayman' fruit at Blacksburg, Va., in 1987.

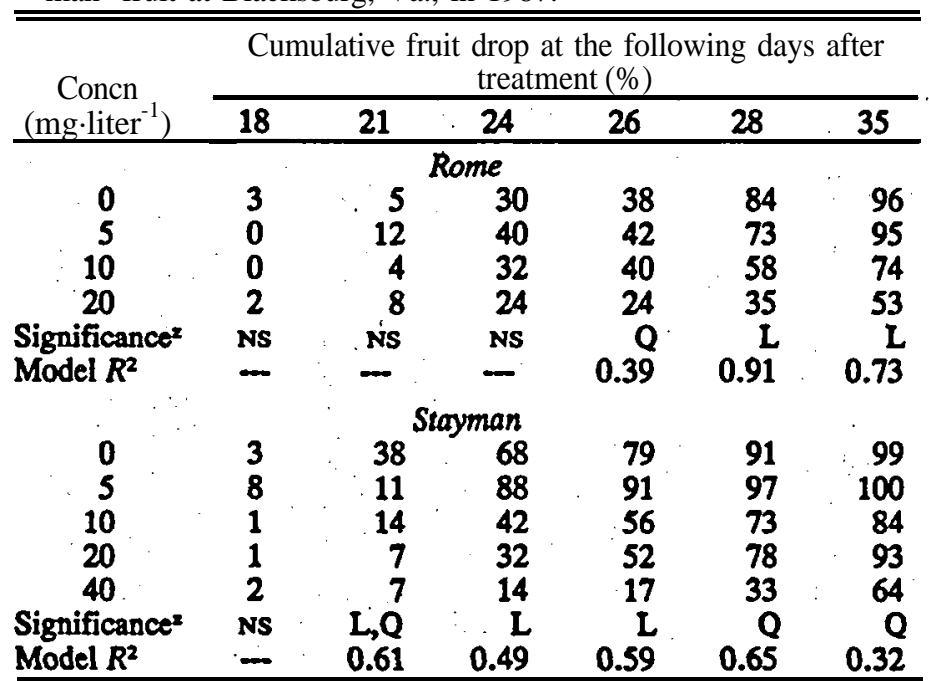

${ }^{\mathrm{z}}$ Statistical significance levels were assessed at $\mathrm{P} \leq 0.05(\mathrm{n}=12$ for 'Rome' and 20 for 'Stayman'); NS represents nonsignificance. and L and $\mathrm{Q}$ represent significant linear and quadratic terms, respectively.

of 'Red Yorking' fruit was reduced nonlinearly With increasing dicamba concentrations (Table 3).

Drop of 'Rome' was not affected by dicamba for 24 DAT, when $24 \%$ to $40 \%$ of the fruit had fallen (Table 4). Fruit drop was negatively related: to dicamba concentration in a quadratic and linear manner at 26 and 28 DAT, respectively. 'Stayman' fruit drop was negatively related to dicamba concentration in a linear manner until 26 DAT, and the relationship was quadratic at 28 and 35 DAT.

1988. Although preharvest drop was less severe than normal, 'Fullred Delicious' fruit drop was negatively and nonlinearly related to dicamba concentration from 37 through 56 DAT in 1988 (Table 5). At 42 DAT, fruit drop did not significantly differ for NAA and dicamba at $10 \mathrm{mg} \cdot \mathrm{liter}^{-1}$, but dicamba was
Table 5. Abscission of 'Fullred Delicious' apples following application of dicamba and NAA in Winchester, Va., in 1988.

\begin{tabular}{|c|c|c|c|c|c|c|}
\hline \multirow[b]{2}{*}{ Chemical } & \multirow{2}{*}{$\begin{array}{c}\text { Conch } \\
\left(\mathbf{m g} \cdot \text { liter }^{-1}\right)\end{array}$} & \multicolumn{5}{|c|}{$\begin{array}{l}\text { Cumulative fruit drop at the } \\
\text { following days after treatment }(\%)\end{array}$} \\
\hline & & 27 & 37 & 42 & 49 & 56 \\
\hline $\begin{array}{l}\text { None } \\
\text { Dicamba }\end{array}$ & $\begin{array}{r}5 \\
10 \\
15 \\
20\end{array}$ & $\begin{array}{l}3 \\
3 \\
1 \\
3 \\
3\end{array}$ & $\begin{array}{r}25 \\
8 \\
2 \\
4 \\
5\end{array}$ & $\begin{array}{r}53 \\
15 \\
4 \\
8 \\
6\end{array}$ & $\begin{array}{r}69 \\
22 \\
8 \\
13 \\
7\end{array}$ & $\begin{array}{l}84 \\
38 \\
20 \\
23 \\
13\end{array}$ \\
\hline $\begin{array}{l}\text { NAA } \\
\text { Significance }^{z}\end{array}$ & 10 & $\mathrm{NS}^{2}$ & & $\begin{array}{r}12 \\
\text { LO }\end{array}$ & $\begin{array}{r}26 \\
L, Q\end{array}$ & $\begin{array}{r}.49 \\
L, Q\end{array}$ \\
\hline Model $\mathrm{R}^{2}$ & & - & 0.66 & 0.82 & 0.83 & 0.74 \\
\hline Contrasts $(\mathrm{P}>\mathrm{F})$ & & & & & & \\
\hline NAA vs. control & - & 0.48 & 0.01 & 0.01 & 0.01 & 0.01 \\
\hline $\begin{array}{l}\text { NAA vs. dicamba at } \\
10 \mathrm{mg} \cdot \text { liter }^{-1}\end{array}$ & & 0.72 & 0.34 & 0.30 & 0.02 & 0.01 \\
\hline
\end{tabular}

${ }^{\mathrm{z}}$ Statistical significance levels for dicamba were assessed at $\mathrm{P} \leq 0.05$ $(\mathrm{n}=30)$; NS represents nonsignificance, and L and $\mathrm{Q}$ represent significant linear and quadratic terms, respectively.

more effective later in the season. Drop of 'Redchief Delicious' fruit was negatively related to dicamba concentration in a linear manner throughout the harvest season (Table 6). At $10 \mathrm{mg} \cdot$ liter $^{-1}$, dicamba and NAA provided similar drop control. Dicamba and fenoprop at $10 \mathrm{mg} \cdot \mathrm{liter}^{-1}$ elicited a similar response until 22 DAT, but fenoprop performed better thereafter. Fenoprop and NAA provided similar drop control until 33 DAT, whereas fenoprop was superior at 37 DAT.

Fruit drop was usually reduced linearly with increasing dicamba concentrations for 'Red Yorking' and 'Winesap', but the relationship was nonlinear for 'Rome' (Table 7). At the same concentration, dicamba provided better drop control than NAA for 'Winesap' on one of three dates, whereas the two materials did not differ for 'Red Yorking' and 'Rome'.

When 'Redchief Delicious' and 'Winesap' fruit were evaluated the day after harvest or after cold storage, flesh firmness, SSC, starch rating, water core, superficial scald, and internal breakdown were not affected by chemical treatment (Table 8).

Table 6. Influence of dicamba, NAA, and fenoprop on abscission of 'Redchief Delicious' fruit in Blacksburg, Va., in 1988.

\begin{tabular}{|c|c|c|c|c|c|c|c|c|}
\hline \multirow[b]{2}{*}{ Chemical } & \multirow{2}{*}{$\begin{array}{c}\text { Concn } \\
\left(\mathrm{mg} \cdot \text { liter }^{-1}\right)\end{array}$} & \multicolumn{7}{|c|}{$\begin{array}{c}\text { Cumulative fruit drop at the following } \\
\text { days after treatment }(\%)\end{array}$} \\
\hline & & 10 & 14 & 19 & 22 & 28 & 33 & 37 \\
\hline None & - & 14 & 20 & 36 & 52 & 65 & 70 & 80 \\
\hline Dicamba & $\begin{array}{r}5 \\
10 \\
15 \\
20\end{array}$ & $\begin{array}{r}14 \\
5 \\
4 \\
5\end{array}$ & $\begin{array}{r}19 \\
6 \\
5 \\
6\end{array}$ & $\begin{array}{r}33 \\
10 \\
7 \\
8\end{array}$ & $\begin{array}{l}42 \\
15 \\
11 \\
9\end{array}$ & $\begin{array}{l}51 \\
22 \\
15 \\
11\end{array}$ & $\begin{array}{l}55 \\
26 \\
18 \\
12\end{array}$ & $\begin{array}{l}64 \\
36 \\
30 \\
19\end{array}$ \\
\hline NAA & 10 & 3 & 3 & 6 & 8 & 10 & 15 & 26 \\
\hline $\begin{array}{l}\text { Fenoprop } \\
\text { Sionificance }\end{array}$ & 10 & & $\begin{array}{r}4 \\
-4\end{array}$ & 4 & & 7 & 8 & 12 \\
\hline Contrasts $(\boldsymbol{P}>\mathbf{F})$ & & 0.11 & 0.19 & 0.38 & 0.46 & 0.51 & 0.53 & 0.52 \\
\hline $\begin{array}{l}\text { NAA vs. dicamba at } \\
\text { NAA vs. dicamba at }\end{array}$ & $\infty$ & 0.02 & 0.01 & 0.01 & 0:01 & 0.01 & 0.01 & 0.01 \\
\hline $10 \mathrm{mg} \cdot$ liter $^{-1}$ & & 0.56 & 0.52 & 0.49 & 0.22 & 0.07 & 0.10 & 0.10 \\
\hline Fenoprop vs. control & $\rightarrow$ & 0.03 & 0.01 & 0.01 & 0.01 & 0.01 & 0.01 & 0.01 \\
\hline $\begin{array}{l}\text { Fenoprop vs. dicamba } \\
\text { at } 10 \mathrm{mg} \cdot \text { liter }^{-1}\end{array}$ & & 0.68 & 0.60 & 0.27 & 0.07 & 0.02 & 0.01 & 0.01 \\
\hline Fenoprop vs. NAA & & 0.86 & 0.90 & 0.67 & 0.57 & 0.55 & 0.20 & 0.03 \\
\hline
\end{tabular}

${ }^{\mathrm{z}}$ Statistical significance. levels were assessed at $\mathrm{P} \leq 0.05(\mathrm{n}=40)$; L represents significant linear terms. 
Table 7. Influence of dicamba and NAA on abscission of 'Red Yorking', 'Winesap', and 'Rome' fruit in Blacksburg, Va., in 1988.

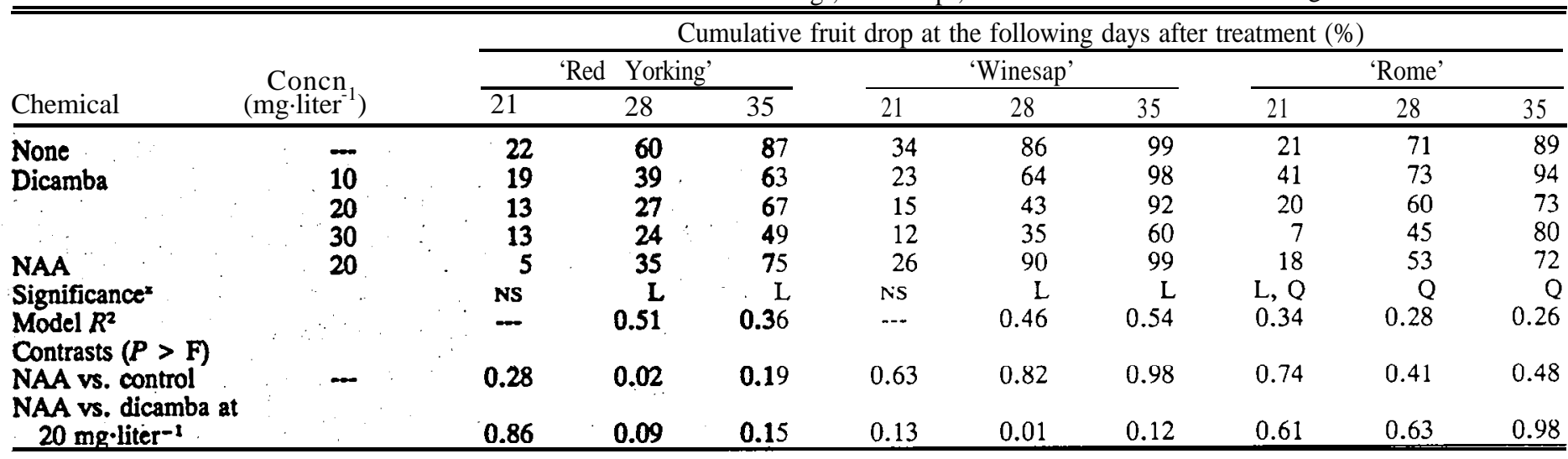

${ }^{\mathrm{z}}$ Statistical significance levels for dicamba only were assessed at $P \leq 0.05(\mathrm{n}=20)$; NS represents nonsignificance, and $\mathrm{L}$ and $\mathrm{Q}$ represent significant linear and quadratic terms, respectively.

Table 8. Quality of 'Redchief Delicious' and 'Winesap' apples at harvest and after cold storage, as influenced by dicamba, NAA, and fenoprop. ${ }^{\mathrm{z}}$

\begin{tabular}{|c|c|c|c|c|c|c|c|c|c|}
\hline $\begin{array}{l}\text { Cultivar and } \\
\text { chemical }\end{array}$ & $\begin{array}{c}\text { Concn } \\
(\mathrm{mg} \cdot \text { liter }\end{array}$ & $\begin{array}{l}\text { Flesh } \\
\text { firmness } \\
-1)(\mathrm{N})\end{array}$ & $\begin{array}{c}\text { Soluble } \\
\text { solids } \\
\text { concn } \\
(\%) \\
\end{array}$ & $\begin{array}{l}\text { Starch } \\
\text { index }^{y}\end{array}$ & $\begin{array}{c}\text { Water } \\
\text { core } \\
\text { rating }\end{array}$ & $\begin{array}{c}\text { Flesh } \\
\text { firmness } \\
(\mathrm{N})\end{array}$ & $\begin{array}{c}\text { Soluble } \\
\text { solids } \\
\text { concn } \\
(\%) \\
\end{array}$ & $\begin{array}{l}\text { Starch } \\
\text { index }^{y}\end{array}$ & $\begin{array}{c}\text { Water } \\
\text { core } \\
\text { rating }\end{array}$ \\
\hline \multicolumn{2}{|c|}{ 'Redchief Delicious' } & \multicolumn{4}{|c|}{30 Sept. 1988} & \multicolumn{4}{|c|}{ 9 Jan. 1989} \\
\hline $\begin{array}{l}\text { NAA } \\
\text { Fenoprop } \\
\text { Significance }\end{array}$ & $\begin{array}{c}5 \\
10 \\
15 \\
20 \\
10 \\
10 \\
(P>F)\end{array}$ & $\begin{array}{c}65.9 \\
65.9 \\
67.6 \\
66.8 \\
67.2 \\
67.6 \\
66.8 \\
0.22\end{array}$ & $\begin{array}{l}13.5 \\
13.3 \\
13.4 \\
13.6 \\
13.6 \\
13.4 \\
13.8 \\
0.86\end{array}$ & $\begin{array}{l}5.5 \\
6.3 \\
5.8 \\
5.8 \\
6.0 \\
6.5 \\
6.2 \\
0.09\end{array}$ & $\begin{array}{l}2.0 \\
2.2 \\
2.3 \\
2.5 \\
2.5 \\
2.5 \\
2.3 \\
0.13\end{array}$ & $\begin{array}{c}52.5 \\
53.4 \\
53.2 \\
52.4 \\
53.3 \\
52.6 \\
51.1 \\
0.13\end{array}$ & $\begin{array}{c}14.0 \\
13.8 \\
13.7 \\
13.7 \\
13.9 \\
13.4 \\
14.1 \\
0.96\end{array}$ & $\begin{array}{l}7.8 \\
7.6 \\
7.8 \\
7.9 \\
7.9 \\
7.9 \\
7.8 \\
0.17\end{array}$ & $\begin{array}{l}1.6 \\
1.6 \\
1.5 \\
2.2 \\
1.8 \\
1.8 \\
1.7 \\
0.09\end{array}$ \\
\hline 'Winesap' & & \multicolumn{4}{|c|}{20 Oct. 1988} & \multicolumn{4}{|c|}{9 Jan. 1989} \\
\hline $\begin{array}{l}\text { None } \\
\text { Dicamba } \\
\text { NAA } \\
\text { Significance }\end{array}$ & $\begin{array}{c}10 \\
20 \\
30 \\
20 \\
(P>F)\end{array}$ & $\begin{array}{c}84.6 \\
82.1 \\
82.0 \\
81.3 \\
81.7 \\
0.08\end{array}$ & $\begin{array}{c}13.7 \\
13.5 \\
13.8 \\
13.9 \\
13.8 \\
0.29\end{array}$ & $\begin{array}{l}4.6 \\
4.0 \\
4.2 \\
4.3 \\
4.4 \\
0.18\end{array}$ & $\begin{array}{l}1.6 \\
1.5 \\
1.4 \\
1.6 \\
1.4 \\
0.36\end{array}$ & $\begin{array}{c}59.8 \\
61.5 \\
58.8 \\
60.1 \\
59.4 \\
0.11\end{array}$ & $\begin{array}{c}15.0 \\
14.3 \\
14.8 \\
15.0 \\
14.9 \\
0.19\end{array}$ & $\begin{array}{l}6.9 \\
6.7 \\
7.1 \\
6.8 \\
6.9 \\
0.33 \\
\end{array}$ & $\begin{array}{l}1.3 \\
1.0 \\
1.3 \\
1.3 \\
1.1 \\
0.42\end{array}$ \\
\hline
\end{tabular}

'Values are means of $\mathbf{4 0}$ observations for 'Redchief Delicious' and 25 observations for 'Winesap'.

${ }^{\mathrm{y}}$ Starch rated as $1=$ entire cut surface stained to $9=$ entire cut surface clear of stain.

${ }^{\mathrm{x}}$ Water core rated as $1=$ none to $7=$ severe.

\section{Discussion}

In this study, the pattern of fruit drop varied considerably with cultivar and season. 'Delicious' drop was more severe in 1987 than 1988, whereas 'Rome' drop was greater in 1988. Although the efficacy of stop-drop treatments varied with the season, which is common for this type of study (Smock et al., 1954), results were generally similar for a given cultivar.

In general, greater concentrations of dicamba were needed to delay fruit abscission of late-season cultivars, which is similar to reports for NAA, fenoprop, and dichlorprop (Southwick et al., 1953; Smock et al., 1954; Marini et al., 1988). For 'Delicious', dicamba at $10 \mathrm{mg} \cdot \operatorname{liter}^{-1}$ was always as effective and usually more effective than NAA at the 'same concentration. However, dicamba appeared less effective than fenoprop for the first 3 weeks after treatment. The effectiveness of dicamba on 'Delicious' usually increased with concentration, but there was little additional drop control at concentrations higher than 20

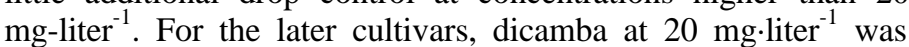

as effective as NAA, or more so, at the same concentration. The optimal dicamba concentration varied with year and cultivar, but there was usually little additional benefit at concentrations higher than $30 \mathrm{mg} \cdot$ liter $^{-1}$.

Although results have varied with time of treatment, concentration, cultivar, and season, drop control with NAA has usually not been long lasting (Looney and Cochrane, 1981; Southwick et al., 1953; Thompson, 1952). In the mid-Atlantic region, NAA is usually expected to provide adequate drop control for 7 to 10 DAT (Crassweller, 1986; Walgenbach, 1987; Pfeiffer, 1989), but, in our experiments, NAA usually provided significant protection against drop for more than 30 DAT, especially with 'Delicious'.

Although variable with cultivar and season, preharvest fenoprop (Southwick et al., 1953; Mattus and Moore, 1954; Mattus et al., 1956; Thompson, 1952) and NAA (Southwick et al., 1953) applications have increased fruit softening. None of the treatments in our study affected fruit firmness, SSC, starch content, or water core development. 
Preharvest applications of dicamba at rates of 10 to 30 mg.liter ${ }^{-1}$ appear equal, or superior, to NAA for delaying fruit abscission without advancing maturity of the major fall apple cultivars. Although additional information concerning optimal timing and possible combination with NAA would be useful, our data indicate that dicamba effectively reduces preharvest fruit drop of apple and is worthy of serious consideration for U.S. Environmental Protection Agency registration.

\section{Literature Cited}

Batjer, L.P. and M.W. Williams. 1966. Effects of N-dimethyl amino succinamic acid (Alar) on watercore and harvest drop of apples.

Proc. Amer. Soc. Hort. Sci. 88:76-79.

Crassweller, R.M. 1986. Tree fruit production guide 1986. Coop. Ext. Serv., The Pennsylvania State Univ., University Park, Pa.

Edgerton, L.J. and G.D. Blanpied. 1970. Interaction of succinic acid 2,2-dimethyl hydrazide, 2-chloroethylphosphonic acid and auxins on maturity, quality and abscission of apples. J. Amer. Soc. Hort. Sci. 95:664-666.

Gardner, F.E., P.C. Marth, and L.P. Batjer. 1940. Spraying with plant growth substances for control of the preharvest drop of apples. Proc.

Amer. Soc. Hort. Sci. 37:415-428

Looney, N.E. and W.P. Cochrane. 1981. Relative effectiveness of, and residue declination values for dichlorprop, fenoprop and nap. thaleneacetic acid used to control preharvest drop of McIntosh apples. Can. J. Plant Sci. 61:87-91.

Marini, R.P. and R. Byers. 1988. Methods for evaluating chemical inhibitors of apple abscission. HortScience 23:849-851.

Marini, R.P., R.E. Byers, D. Sowers, M.E. Marini, and R.W. Young.
1988. Fruit abscission, fruit quality, and residue levels of dichlorprop used to control preharvest drop of apple. HortScience 23:717719.

Mattus, G.E. and R.C. Moore. 1954. Preharvest growth regulator sprays on apples. I. Drop and maturity 1952 and 1953. Proc. Amer. Soc. Hort. Sci. 64:199-208.

Mattus, G.E., R.C. Moore, and H.A. Rollins, Jr. 1956. Preharvest growth regulator sprays on apples. II. Drop and maturity for 1954 and 1955. Proc. Amer. Soc. Hort. Sci. 67:63-67.

Pfeiffer, D.G. 1989. 1989-1990 Spray bulletin for commercial tree fruit growers. Virginia Coop. Ext. Publ. 456-419.

Poapst, P.A., G.M. Ward, and W.R. Phillips. 1959. Maturation of McIntosh apples in relation, to starch loss and abscission. Can. J. Plant Sci. 39:257-263.

Pollard, J.E. 1974. Effects of SADH, ethephon and 2,4,5-T on color and storage quality of 'McIntosh' apples. J. Amer. Soc. Hort. Sci. 99:341-343

SAS Institute, Inc. 1982. SAS user's guide and SAS statistical procedures. SAS Institute, Cary, NC.

Smock, R.M., L.J. Edgerton, and M.B. Hoffman. 1954. Some effects of stop drop auxins and respiratory inhibitors on the maturity of apples. Proc. Amer. Soc. Hort. Sci. 63:211-219.

Southwick, F.W., I.E. Demoranville, and J.F. Anderson. 1953. The influence of some growth regulating substances on preharvest drop, color, and maturity of apples. Proc. Amer. Soc. Hort. Sci. 61:155162.

Thompson, A.H. 1952. Further experiments with 2,4,5-trichlorophenoxypropionic acid sprays for control of the preharvest drop of apples. hoc. Amer. Soc. Hort. Sci. 60:175-183.

Walgenbach, J.F. 1987. Agricultural chemicals for North Carolina apples. North Carolina Agr. Ext. Serv.

J. AMER. Soc. Hort. SCI. 115(3):394-400. 1990.

\section{Thinning Activity of Benzyladenine on Several Apple Cultivars

\author{
Duane W. Greene and Wesley R. Autio \\ Department of Plant and Soil Sciences, University of Massachusetts, Amherst, MA 01003
}

Paul Miller

Victorian Department of Agriculture, Horticultural Research Institute, Knoxfield, Victoria 3180, Australia

Additional index words. Malus domestica, BA, fruit set, flowering, return bloom, carbaryl, NAA, ethephon, bioregulator

Abstract. Postbloom sprays of BA thinned 'McIntosh', 'Delicious', 'Golden Delicious', 'Mutsu, 'Empire', and 'Abas' apples. BA at 75 to $100 \mathrm{mg} \cdot$ liter $^{-1}$ was equal to NAA at 6 to $7.5 \mathrm{mg} \cdot$ liter $^{-1}$ or carbaryl at 600 to $800 \mathrm{mg} \cdot$ liter $^{-1}$. BA increased fruit size, flesh firmness, and soluble solids concentration (SSC) on all cultivars evaluated. Since BA is applied during the time when cell division is occurring, it is concluded that the increased fruit size and flesh firmness were due to Increased cell numbers. Increased SSC was not due solely to increased leaf : fruit ratio. Thinning with BA was additive with other chemical thinners and no interactions were found on fruit abscission. In most eases, BA increased return bloom. Chemical names used: $\mathrm{N}$-(phenylmethyl)1H-purine-6-amine [benzyladenine (BA)]; 1naphthaleneacetic acid (NAA); 1-naphthalenyl methylcarbamate (carbaryl); butanedioic acid mono(2,2dimethylhydrazide (daminozide); (2-chloroethyl)phosphonic acid (ethephon).

Chemical thinning is one of the most important yet one of the most difficult plant growth regulator practices to perform in

Received for publication 24 Apr. 1989. Paper no. 2924, Massachusetts Agricultural Experiment Station, Univ. of Massachusetts at Amherst. We gratefully acknowledge the support and assistance by the Victorian Dept. of Agriculture while D.W.G. was on sabbatical leave at the Horticultural Research Institute. Knoxfield, Australia. The cost of publishing this paper was defrayed in part by the payment of page charges. Under postal regulations, this paper therefore must be hereby marked advertisement solely to indicate this fact. modem apple production (Looney, 1986). Cost of chemical thinning materials and their application are relatively low, yet the cost is perilously high if over-thinning or under-thinning occurs.

The chance of over-thinning with carbaryl is not great, since carbaryl is not a potent thinner and, at the concentrations generally used, its response is not concentration dependent (Forshey, 1987). Frequently, carbaryl may not thin adequately. This has been true in recent years when there is an increasing demand for larger fruit (Greene and Autio, 1988). NM and ethephon 